911.2:551.4

\author{
- еремх \\ ьвівський н ціон льний університет імені в н \\ вул. . орошенк , 41, м. ввів, 79000, кр їн
}

ро н лізов но зміст поняття “природний потенці л л ндш фту”. озкрито його змістовну суть і структуру, що охоплює природно-ресурсний, екологічний потенці ли т потенці л стійкості, які, відповідно, скл д ються з низки ч сткових потенці лів.

лючові слов : потенці л, л ндш фт, природний територі льний комплекс, природний потенці л, природно-ресурсний потенці л, екологічний потенці л, потенці л стійкості л ндш фту.

ермін “потенці л” походить від л тинського potential i озн ч є силу, прихов ні можливості - н явні сили, з п си, з соби, що можуть бути використ ні [1, с. 428].

. щенко т . фімов [11], термін “потенці л” у широкому розумінні тр ктують як можливості, н явні сили, з п си, які можуть бути використ ні для будь-чого, бо як сукупність з собів, необхідних для чого-небудь. словнику іншомовних слів цей термін розтлум чено як "н явні з соби, т кож з соби, що можуть бути мобілізов ні, використ ні для досягнення певної мети, розв'яз ння якогось з вд ння...” [10, с. 244]. цьому ж словнику з зн чено, що термін “потенційний” озн ч є “т кий, що існує у прихов ному вигляді, можливий” [10, с. 245]. тже, потенці л, потенці льний озн ч ють н явність у чомусь прихов них можливостей, які ще не виявилися.

ермін “потенці л” широко використовують у різних г лузях н уки. прикл д, в економіці з стосовують поняття: потенці л трудових ресурсів, економічний потенці л території, в м тем тиці, фізиці, хімії, біології т техніці - потенці л дії, хімічний потенці л, потенці л електром гнітного поля [3, с. 12].

чені-геогр фи терміном потенці л позн ч ють вл стивості природних територі льних комплексів ( ), в жливих з погляду господ рської діяльності людини, н прикл д, природний потенці л, природно-ресурсний потенці л, рекре ційний потенці л, екологічний потенці л, природоохоронний потенці л, потенці л стійкості тощо.

сфері природничих т фізико-геогр фічних досліджень більшість вторів н д $є$ перев гу ресурсному тр ктув нню термін потенці л, тобто цей термін розуміють як 6 зу ресурсів . ке тлум чення потенці лу, як з зн ч $є$. с ченко [5], м є в жливе зн чення для пл нув ння т упр вління господ рською діяльністю, одн к не вичерпує всіх його вл стивостей, оскільки потенці л є функціон льним трибутом ресурсів і х р ктеризує зд тність л ндш фту з безпечити викон ння ним певної функції, тому його природний потенці л в рто розуміти як єдність структури і функцій л ндш фту, вияв їхнього вз ємозв'язку.

риродні ресурси, згідно з . е еймерсом - це природні об'єкти т явищ , що їх використовують у теперішньому і м йбутньому для прямого і непрямого спожив ння т

(C) еремх ., 2012 
які сприяють створенню м тері льних $б$ г тств, відтворенню трудових ресурсів, підтримці умов існув ння людини, підвищенню якості життя. · еймерс говорить про природні ресурси як про тіл і сили природи (природні бл г ), суспільн корисність яких позитивно бо нег тивно змінюється вн слідок трудової діяльності людини [8].

тже, є підст ви вв ж ти, що термін потенці л є уз г льненою, збірною х р ктеристикою ресурсів, як прив'яз н до місця т ч су, охоплює сукупність п р метрів, предметів, явищ. оч існують сутнісні відмінності між поняттям потенці л і ресурси, ці поняття не в рто протист вляти.

сновн відмінність природного потенці лу від природного ресурсу поляг є в тому, що потенці л чітко пов'яз ний з конкретним з вд нням, для вирішення якого його визН ч ють, природний ресурс хоч й розгляд ють у контексті призн чення, проте його зв'язок з конкретним користув чем не є обов'язковим. прикл д, водні ресурси території можн використовув ти і в рекре ційній діяльності, і в промисловості, і сільському господ рстві ( н логічно з стосовують і лісові ресурси). тже, термін природний потенці л є ширшим, ніж поняття природні ресурси. одноч с поняття природний потенці л є ширшим, ніж потенці л природних ресурсів.

ермін потенці л широко з стосовують у комплексній фізичній геогр фії. окрем , існує кільк визн чень потенці лу л ндш фту. л ндш фтозн встві т л ндш фтній екології концепцію природного потенці лу л ндш фту (у з г льному розумінні термін л ндш фт як синонім до природного територі льного комплексу), як з зн ч $є$ родзинський (1993), розробили Х. обек, . м мітхюзен (1948), . ефф (1966, 1973); . зе $(1976,1978), \quad$ зур, . рдош (1984), . юмін (1990), . с ченко $(1991,1992) \mathrm{T}$ ін.

ід поняттям “потенці л” у цьому р зі розуміють внутрішню природну вл стивість л ндш фту ( ), яку він м є стосовно будь-якої функції, нез лежно від того, виконує він іiї в цей ч с чи ні [2, с. 181]. ункції будь-якого л ндш фту визн чені суспільством бо суспільною діяльністю людини. . родзинський н голосив, що функція геосистеми (л ндш фту) є поняття більш нтропічне, ніж природне, н відміну від їі потенці лу, який визн ч ється природними особливостями геосистеми [2, с. 180].

скільки, з . родзинським [2], стосовно кожної функції геосистему ( $\quad$ ) х p ктеризує певний природний потенці л - зд тність виконув ти цю функцію, зберіг ючи свою структуру т природні особливості, то $є$ підст ви вв ж ти, що природний потенці л - його одн 3 н йв жливіших вл стивостей.

словнику “ хр н л ндш фтов” потенці л л ндш фту ( ) потр ктов но як х p ктеристику міри можливого викон ння л ндш фтом соці льно-економічних функцій, відбивний ступінь можливої уч сті л ндш фту у з доволенні різном нітних потреб суспільств [7, с. 163]. одноч с н голошено, що потенці л л ндш фту з лежить від його природних умов, н пряму і форм використ ння. цьому ж словнику окреслено зміст ч сткових потенці лів л ндш фту ( ): біотичний - зд тність л ндш фту продукув ти біом су, створюв ти умови для постійного повторення цього процесу; водний - зд тність л ндш фту тр нсформув ти отрим ну 3 тмосфери вологу т к, щоб ії не тільки використовув л рослинність й щоб вон утворюв л порівняно з мкнутий кругообіг води, який може бути з стосов ний людиною; мінер льно-ресурсний - зд тність л ндш фту кумулюв ти і змінюв ти (упродовж геологічних періодів) окремі речовини бо носії прихов ної енергії, як корисні коп лини можн використовув ти для потреб людств ; будівельний - н явність у л ндш фті необхідних природних умов для будівництв (будинків, комунік цій т ін.) площ; рекре ційний - сукупність природних 
і культурних умов, які зумовлюють позитивний вплив н людський орг нізм, шляхом сукупності фізичних і психологічних чинників з безпечують відновлення пр цезд тності людини. иділяють т кож потенці л с моочищення - зд тність л ндш фту тр нсформув ти, розкл д ти невідомі йому речовини різного походження т к, щоб не виникло неочікув них н слідків для здоров'я людини і для господ рств : біотичний потенці л регулюв ння - зд тність л ндш фту зберіг ти бо відновлюв ти генофонд, біологічне різном ніття і стійкість екосистем [7, с. 164-165].

ищенко під л ндш фтним потенці лом розуміє фізичний ст н і речовинноенергетичну з безпеченість геогр фічних л ндш фтів, які визн ч ють їхню зд тність виконув ти природоохоронні т соці льно-економічні функції і з довольняти суспільні потреби через різні види природокористув ння [12, с. 73].

меж х з г льного бо територі льного л ндш фтного потенці лу . ищенко [12] виділяе т кі ч сткові л ндш фтні потенці ли: земельно-ресурсний, мінер льно-ресурсний, волого-тепловий і водний, біотичний (зд тність геогр фічного л ндш фту продукув ти й відтворюв ти орг нічну речовину, постійно відновлюв ти цю вл стивість, використовуючи біотичний кругообіг), будівельний, рекре ційний, с моочищення, біотичної регенер ції, естетичний, с морегуляційний тощо.

. істовський визн ч є л ндш фтний потенці л як “усі з соби і в ртості л ндш фту ( ) (м тері льні т естетичні риси), що відобр ж ють його зд тність 3 довольняти людські потреби (фізичні т психічні) тепер і в м йбутньому, т кож підтримують цю зд тність ун слідок дії в л ндш фті мех нізмів с морегуляції т стійкості”. ін виділяе т кі групи ч сткових потенці лів л ндш фту: ) потенці ли ресурсно-ужиткові: ) основні: 1) біотичної продуктивності, 2) рекре ційний, 3) прид тності для з будови, 4) сировинний; б) допоміжні: 5) з безпечення водою, 6) тмосферний; ) потенці ли, які з безпечують природну зрівнов женість л ндш фту: 7) с морегуляційно-витрив лісний [13, с. 367].

оняття природного потенці лу л нш фту (у регіон льному розумінні терміну л ндш фт), обгрунтов не . олнцевим (1948) т розвинене . с ченком [4].

. олнцев 3 зн чив, кожен геогр фічний л ндш фт м є певні внутрішні вл стиві тільки йому потенційні природні можливості, котрі визн ч ються, з одного боку, геогр фічною зумовленістю, як 3 лишил сь ч сто від дуже д леких ч сів, 3 іншого - тими можливостями, які відкрив є перед ним суч сн структур геогр фічного процесу, як строго лімітує природний потенці л л ндш фту [9, с. 22].

лі . олнцев н голосив н необхідності розрізняти дв бсолютно різні спекти поняття природного потенці лу л ндш фту, с ме: природний потенці л і культурнотехнічний потенці л. риродний потенці л - це ті внутрішні можливості, які д ні л ндш фту с мою природою і які ми, геогр фи, зобов'яз ні пр вильно визн чити й оцінити. ультурно-технічний потенці л безперервно і швидко зрост є, з вдяки чому можливості використ ння людиною природного л ндш фту т кож зрост ють - те, що ще вчоp було неможливим бо м рним, сьогодні виявляється цілком можливим, цінним і необхідним [9, с. 22].

процесі л ндш фтозн вчих досліджень, згідно з . с ченком [4] в жливим є виділення т ких скл дових природного потенці лу л ндш фту (див. рисунок): природноресурсного й екологічного потенці лів т потенці лу стійкості.

окрем , . с ченко з зн чив, що природно-ресурсний потенці л л ндш фту - це деякий обмежений (кінцевий) з п с виробничих ресурсів, ... теоретично доступний для використ ння в будь-якій відд леній перспективі [5, с. 220]; екологічний потенці л 
л ндш фту - це його зд тність з довольняти потреби людини у всіх необхідних первинних (тобто не пов'яз них з виробництвом) з соб х існув ння - повітрі, світлі, теплі, питній воді, джерел х х рчових продуктів, т кож у природних умов х трудової діяльності, відпочинку, духовного розвитку [6, с. 31]; потенці л стійкості л ндш фту це зд тність протистояти зовнішнім, у тому числі техногенним вплив м, включ ючи с моочищення від техногенних домішок, відновлюв тись після порушень тощо [4, c. 306].

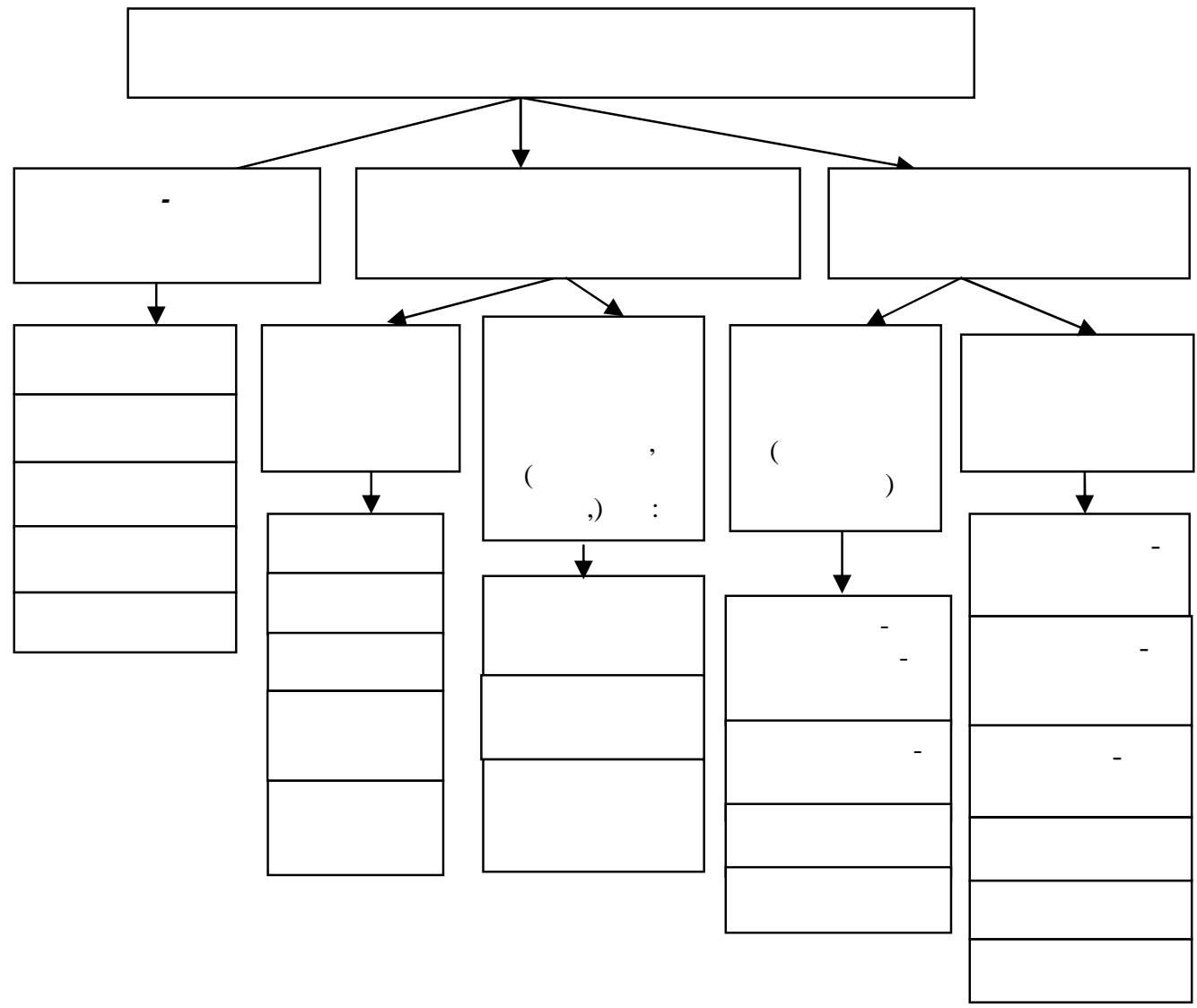

кл дові природного потенці лу л ндш фту, з с ченком [4], з доповненням.

риродно-ресурсний, екологічний т потенці л стійкості, відповідно, скл д ються 3 ч сткових потенці лів (див. рисунок). окрем , скл довими природно-ресурсного потенці лу є т кі потенці ли: лісовий, водний, рекре ційний, землеробський, рекре ційний т з будови; екологічного - первинних з собів існув ння, що включ є потенці ли повітря, світл , тепл , питної води, х рчових продуктів т потенці л вторинних з собів існув ння (потенці ли природних умов для трудової діяльності, відпочинку, духовного розвитку); потенці л стійкості - стійкості до природних процесів (охоплює потенці ли стійкості геолого-геоморфологічних, метеорологічних, гідрологічних т біологічних процесів; стійкості до нтропогенних н в нт жень (потенці ли стійкості до лісогоспод рських, сільськогоспод рських, з будовних і промислових н в нт жень). 
тже, природний потенці л л ндш фту є його вл стивістю, як х р ктеризує внутрішні можливості л ндш фту, пов'яз ні зі зд тністю виконув ти ним певні функції, тобто з довольняти різном нітні потреби людини (ресурсні, екологічні) т зберіг ти свою структуру і вл стивості. ін є сукупністю ч сткових потенці лів, які об'єднують у три групи - природно-ресурсний, екологічний т потенці л стійкості. ого пізн ння повинно опир тись н вивчення генезису, структури, дин міки і ст нів л ндш фтів т їхніх морфологічних одиниць - місцевостей, урочищ і ф цій.

оняття природного потенці лу л ндш фту м є в жливе прикл дне зн чення. н слідок зрост ння нтропогенних н в нт жень н природу, висн ження природних ресурсів, збільшення обсягів екологічно шкідливих викидів, зниження якості середовищ прожив ння людей інтерес до вивчення т оцінки природного потенці лу території зН чно зрост $є$.

ндш фти постійно змінюються, тому їхній природний потенці л як вз ємозумовлен сукупність окремих потенці лів, не з лиш ється постійним, змінюється р зом 3 с мими л ндш фт ми. огляду н це, дуже в жливо вр ховув ти дин мічні зміни л ндш фтів і тенденції їхнього розвитку [9].

в гу треб зосереджув ти н вивченні як ч сткових, т к і з г льного природного потенці лів л ндш фту. скільки окремі потенці ли л ндш фту досліджують уже досить д вно, то сьогодні особливо кту льним є пит ння синтетичної оцінки цілісного природного потенці лу л ндш фту.

1. ольш я советск я энциклопедия. - . . ов. энциклопедия, 1975. - Т. 20. - 608 с.

2. родзинський . . снови л ндш фтної екології / . . родзинський. - . : ибіль, 1993. $224 \mathrm{c}$.

3. олубець . . кологічний потенці л н земних екосистем / . . олубець, . . рискевич,

. . рок, . . озловський. - ьвів : оллі, 2003. - 180 с.

4. c ченко . . ндш фтоведение и физико-геогр фическое р йониров ние / . . с ченко. . : ысш. шк., 1991. -365 с.

5. с ченко .. есурсный потенци л л ндш фт и природно-ресурсное р йониров ние / . . с с ченко // зв. . -1992. - .124. - ып. 3. - .219-232.

6. с ченко . . ведение в экологическую геогр фию : учеб. пособие / . . с ченко. - . . зд-во .- етерб. ун-т , 2003.- 192 с.

7. хр н л ндш фтов. олковый слов рь. - . : рогрессе, 1982. -272 с.

8. еймерс . . лов рь терминов и понятий, связ нных с охр ной живой природи / . . еймерс, . . блоков. - . : ук , 1982. $-144 \mathrm{c}$.

9. олнцев . . чение о л ндш фте (избр нные труды) / . . олнцев. - . : зд-во оск. ун-т , 2001. $-384 \mathrm{c}$.

10. уч сний словник-мінімум іншомовних слів: лизько 6000 слів. - 3-тє вид., випр. і доп. - . . овір , 2005. -445 с.

11. лум чний словник-мінімум укр їнської мови: близько 9000 слів / укл. . . щенко, . . фімов. - 3-те вид., випр. і доп. - . : овір , 2006. - 607 с.

12. ищенко . . отенці л л ндш фтний // еогр фічн енциклопедія кр їни. - . : , 1993. - . 3. - .73-74.

13. Kistowski M. Metoda oceny potencjału krajobrazu obszarów młodoglacjalnych / . Kistowski // Przegląd geograficzny. - 1996. - . 68., Z. 3-4. - S. 368-386.

m ття: н дійшл до редколегії 04.10.2011 прийнят до друку 20.12.2011 


\section{THE CONCEPT OF NATURAL POTENTIAL OF LANDSCAPE}

\section{. Cheremkha}

Ivan Franko National University of Lviv, . Doroshenko St., 41, UA - 79000 Lviv, Ukraine

Analyzed the content of the concept of natural potential of landscape. Reveals the essence of its content and structure, which includes natural resources, environmental potential and potential of sustainability, which consist of a series of partial potentials.

Key words: potential, landscape, natural territorial complex, natural potential, natural resource potential, ecological potential, the potential stability of the landscape.

\section{- еремх}

ввовский н цион льный университет имени в н

$$
\text { ул. . орошенко, 41, г. ьвов, 79000, кр ин }
$$

ро н лизиров но содерж ние понятия “природный потенци л л ндш фт ”. скрыто его содерж тельную суть и структуру, котор я включ ет природно-ресурсный, экологический потенци лы и потенци л устойчивости, которые состоят из ряд ч стных потенци лов.

лючевые слов : потенци л, л ндш фт, природный территори льный комплекс, природный потенци л, природно-ресурсный потенци л, экологический потенци л, потенци л устойчивости л ндш фт . 